\title{
ANALISIS PENGENDALIAN KUALITAS PRODUK KORAN PADA PT. RADAR SULTENG MEMBANGUN DI KOTA PALU
}

\author{
ZAHRO'IN NITAFIYAH \\ SAHARUDDIN KASENG \\ SYAMSUDDIN \\ Program Studi S1 Manajemen, Fakultas Ekonomi, Universitas Tadulako \\ Email: zahroinitafia@gmail.com, saharuddin.kfamily@yahoo.com,Syamsingga@yahoo.com
}

\begin{abstract}
This study aims to determine how the implementation of quality control using statistical aids is useful in an effort to control the level of product damage in the company. Quality control analysis is carried out using statistical tools in the form of check sheets and p control maps. Check sheets are used to present data to make it easier to understand data for the purposes of subsequent analysis. P control maps are used to monitor damaged products whether they are still in control or not.

The results of the $P$ control chart analysis show that the process has been carried out well. This can be seen in the final product quality control chart with the final number of CL values showing 0.0049, UCL 0.0091, LCL 0.0007 with a proportion of 0.0050 defects which means that the quality control process is within controlled limits because the value of the defect proportion is smaller than the UCL value.
\end{abstract}

Keywords: Quality Control, Statistical Tools, Control Maps $p$

\section{Abstrak}

Penelitian ini bertujuan untuk mengetahui bagaimana pelaksanaan pengendalian kualitas menggunakan alat bantu statistik bermanfaat dalam upaya mengendalikan tingkat kerusakan produk di perusahaan. Analisis pengendalian kualitas dilakukan menggunakan alat bantu statistik berupa check sheet dan peta kendali p. Check sheet digunakan untuk menyajikan data agar memudahkan dalam memahami data untuk keperluan analisis selanjutnya. Peta kendali $\mathrm{p}$ digunakan untuk memonitor produk yang rusak apakah masih berada dalam kendali atau tidak.

Hasil analisis peta kendali $p$ menunjukkan bahwa proses sudah terlaksana dengan baik. Hal ini dapat dilihat pada grafik kendali kualitas produk akhir dengan jumlah akhir nilai CL menunjukkan 0.0049, UCL 0.0091 , LCL 0.0007 dengan proporsi cacat 0.0050 yang berarti proses pengendalian kualitas berada dalam batas terkendali karena nilai proporsi cacat lebih kecil dari nilai UCL.

Kata kunci: Pengendalian Kulitas, Alat Bantu Statistik, Peta Kendali p

\section{PENDAHULUAN}

Dewasa ini, persaingan bisnis akan semakin sengit dan ketat karena akan dimulainya era globalisasi. Setiap usaha dalam persaingan tinggi dituntut untuk selalu berkompetisi dengan perusahaan lain di dalam industri yang sejenis. Salah satu cara agar bisa memenangkan kompetisi tersebut adalah dengan memberikan perhatian penuh terhadap kualitas produk yang dihasilkan oleh perusahaan sehingga bisa mengungguli produk yang dihasilkan oleh pesaing.

Kualitas produk yang baik dihasilkan dari pengendalian kualitas yang baik pula. Maka banyak perusahaan yang menggunakan metode tertentu untuk menghasilkan suatu produk dengan kualitas yang baik. Untuk itulah pengendalian kualitas dibutuhkan untuk menjaga agar produk yang dihasilkan sesuai dengan standar kualitas yang berlaku. Standar kualitas yang dimaksud adalah bahan baku, proses produksi, dan produk jadi (M.N Nasution, 2005). Statistic Quality Control (SQC) sebagai alat pengawasan kualitas produksi dapat membantu perusahaan apakah produk yang dihasilkan masih berada dalam batas-batas kontrol atau tidak dari proses awal kualitas bahan, proses produk, produk akhir.

PT. Radar Sulteng merupakan perusahaan pers yang bergerak dalam industri penerbitan dan percetakan surat kabar harian yang berdiri sejak 28 Oktober 2001 di Kota Palu Sulawesi Tengah. Surat kabar ini termasuk dalam grup Jawa Pos. Kantor pusatnya terletak di Jl. Yos Sudarso No. 9 Palu. Belasan 
tahun di dunia pemberitaan dan adanya perubahan zaman yang dibarengi oleh perkembangan dari berbagai aspek seperti aspek ekonomi, teknologi maupun bisnis yang pesat, perusahaan harus mampu bertahan, beradaptasi, dan bersaing secara ketat dengan para kompetitor agar dapat terus melangkah dari berbagai tantangan dan permasalahan bisnis yang ada dengan terus melakukan perbaikan, penyempurnaan, dan memiliki terobosan baru serta perusahaan harus tetap memusatkan perhatian kepada pelanggannya.

PT. Radar Sulteng Membangun juga menerapkan pengendalian kualitas pada proses produksi percetakannya agar bisa mempertahankan kualitas produk yang dihasilkan. Akan tetapi dalam kenyataan di lapangan (saat proses produksi) masih terdapat beberapa masalah yang dihadapi sehingga menimbulkan produk yang belum memenuhi standar kualitas yang ditentukan. Jenis kecacatan produk Koran yang sering terjadi di PT. Radar Sulteng Membangun yaitu sebagai berikut:

1. Koran kotor (terdapat bercak tinta di lembaran koran)

2. Warna kabur (penyerapan tinta tidak merata)

3. Tidak register (warna satu dengan yang lain belum menyatu)

4. Lipatan tidak simetris.

5. Terpotong (terdapat bagian yang terpotong melebihi garis tepi)

Produk cacat yang terjadi pada 1 eksemplar koran hasil produksi dimungkinkan terdapat tidak hanya satu jenis kerusakanan, akan tetapi bisa lebih dari satu macam. Oleh karena itu, jenis kerusakan yang dicatat adalah jenis kerusakan paling dominan yang terdapat pada 1 eksemplar koran hasil produksi.

\section{KAJIAN LITERATURE DAN PENGEMBANGAN HIPOTESIS}

Menurut Ariani (2003) Pengendalian kualitas statistik merupakan teknik penyelesaian masalah yang digunakan untuk memonitor, mengendalikan, menganalisis, mengelola, dan memperbaiki produk dan proses menggunakan metode-metode statistik. Pengendalian kualitas statistik (statistical quality control) sering disebut sebagai pengendalian proses statistik (statistical process control) merupakan dua istilah yang saling dipertukarkan, yang apabila dilakukan bersama-sama maka pemakai akan melihat gambaran kinerja proses masa kini dan masa mendatang (Cawley dan Harrold, 1999).

Tujuan dari pengendalian kualitas menurut Sofjan Assauri (2008) adalah:

1. Agar barang hasil produksi dapat mencapai standar kualitas yang ditetapkan.

2. Mengusahakan agar biaya inspeksi dapat menjadi sekecil mungkin.

3. Mengusahakan agar biaya desain dari produk dan proses dengan menggunakan kualitas produksi tertentu dapat menjadi sekecil mungkin.

4. Mengusahakan agar biaya produksi dapat menjadi serendah mungkin.

Menurut Montgomery (2001), faktor-faktor yang mempengaruhi pengendalian kualitas yang dilakukan perusahaan adalah:

1. Kemampuan proses

Batas-batas yang ingin dicapai haruslah disesuaikan dengan kemampuan proses yang ada. Tidak ada gunanya mengendalikan suatu proses dalam batas-batas yang melebihi kemampuan atau kesanggupan proses yang ada.

2. Spesifikasi yang berlaku

Hasil produksi yang ingin dicapai harus dapat berlaku, bila ditinjau dari segi kemampuan proses dan keinginan atau kebutuhan konsumen yang ingin dicapai dari hasil produksi tersebut. Dapat dipastikan dahulu apakah spesifikasi tersebut dapat berlaku sebelum pengendalian kualitas pada proses dapat dimulai.

3. Tingkat ketidaksesuaian yang dapat diterima

Tujuan dilakukan pengendalian suatu proses adalah dapat mengurangi produk yang berada di bawah standar seminimal mungkin. Tingkat pengendalian yang diberlakukan tergantung pada banyaknya produk yang berada dibawah standar.

4. Biaya kualitas 
Sangat mempengaruhi tingkat pengendalian dalam menghasilkan produk dimana biaya mempunyai hubungan yang positif dengan terciptanya produk yang berkualitas.

Pengendalian kualitas secara statistik dengan menggunakan SPC (Statistical Process Control) dan SQC (Statistical Quality Control), mempunyai 7 (tujuh) alat statistik utama yang dapat digunakan sebagai alat bantu untuk mengendalikan kualitas sebagaimana disebutkan juga oleh Heizer dan Render dalam bukunya Manajemen Operasi (2006:263-268) antara lain yaitu: check sheet, histogram, control chart, diagram pareto, diagram sebab akibat, scatter diagram dan diagam proses. Menurut Prawirosentono (2007) Peta kendali digunakan untuk membantu mendeteksi adanya penyimpangan dengan cara menetapkan batas-batas kendali:

1. Upper control limit / batas kendali atas (UCL)

Merupakan garis batas atas untuk suatu penyimpangan yang masih diizinkan.

2. Central line / garis pusat atau tengah (CL)

Merupakan garis yang melambangkan tidak adanya penyimpangan dari karakteristik sampel.

3. Lower control limit / batas kendali bawah (LCL)

Merupakan garis batas bawah untuk suatu penyimpangan dari karakteristik sampel.

\section{Gambar 1. Kerangka Pemikiran}

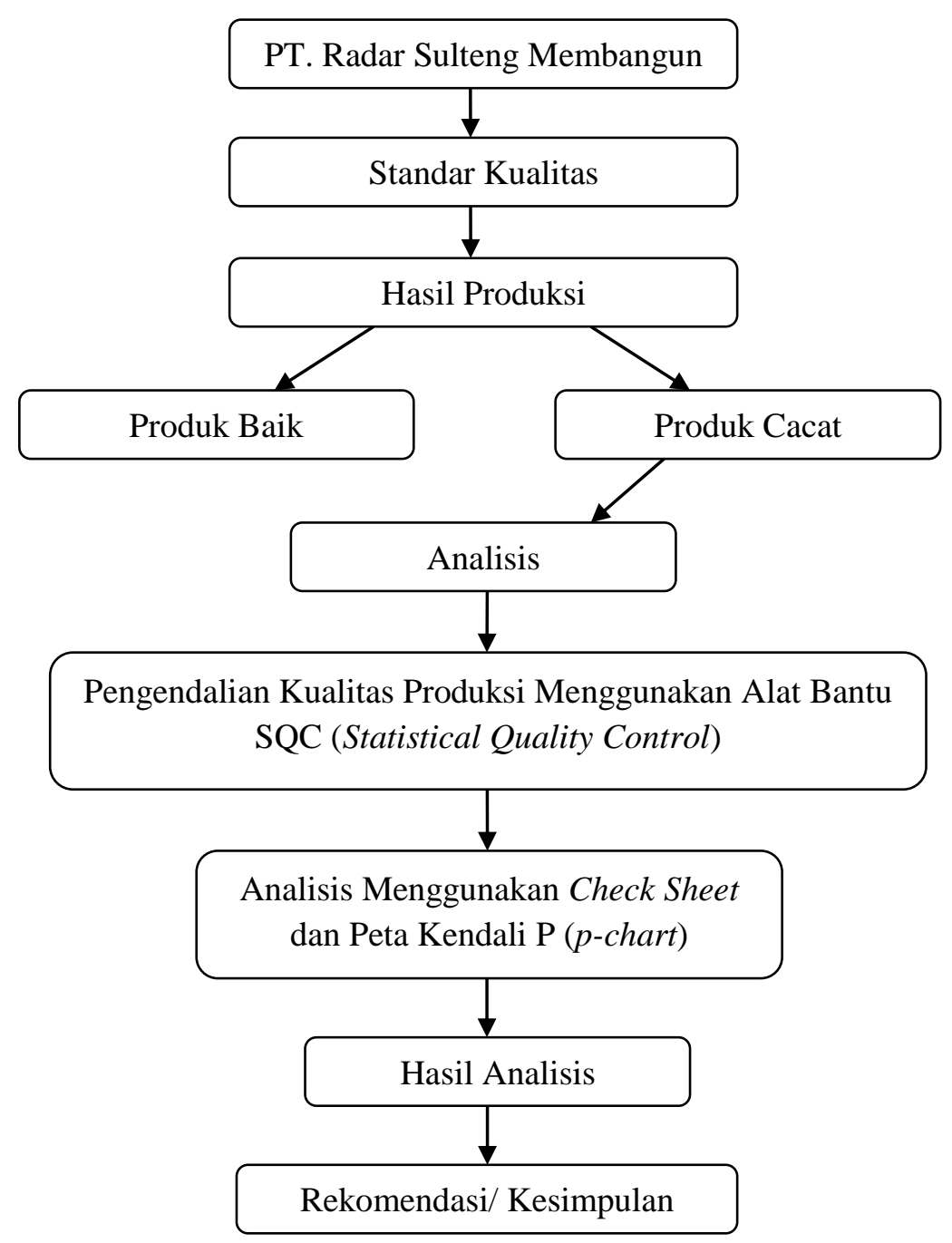




\section{METODE PENELITIAN}

Penelitian ini merupakan jenis penelitian deskriptif dilakukan melalui statistika deskriptif yaitu statistik yang digunakan untuk menganalisis data dengan cara mendeskriptifkan atau menggambarkan data yang telah terkumpul sebagaimana adanya tanpa bermaksud membuat generalisasi hasil penelitian (Sugiyono:2014).

Penelitian ini penulis berusaha mengungkapkan metode pengendalian kualitas yang tepat digunakan oleh perusahaan dan mencoba untuk menganalisis sejauh mana kegagalan produksi koran yang dilakukan oleh surat kabar Radar Sulteng yang tidak dapat ditoleransi. Teknik pengumpulan data yang dilakukan adalah: (1) Observasi, Pengamatan atau peninjauan secara langsung di tempat penelitian yaitu di PT. Radar Sulteng Membangun dengan mengamati sistem atau cara kerja pegawai yang ada, mengamati proses produksi dari awal sampai akhir, dan kegiatan pengendalian kualitas. (2) Wawancara, suatu cara untuk mendapatkan data atau informasi dengan tanya jawab secara langsung pada orang yang mengetahui tentang obyek yang diteliti, yakni dengan pihak manajemen/karyawan PT. Radar Sulteng Membangun yaitu untuk mendapatkan data mengenai jenis-jenis produk cacat dan penyebabnya, proses produksi serta bahan baku yang digunakan. (3) Dokumentasi, mempelajari dokumen-dokumen perusahaan yang berupa laporan kegiatan produksi, laporan jumlah produksi dan jumlah produk cacat, rencana kerja, serta dokumen kepegawaian.

Pengolahan data yang diperoleh digunakan alat bantu statistik yang terdapat pada Statistical Quality Control (SQC) dan Stastitical Process Control (SPC). Adapun langkah-langkahnya adalah sebagai berikut:

1. Mengumpulkan data menggunakan check sheet

Data yang diperoleh dari perusahaan terutama yang berupa data produksi dan data produk cacat kemudian disajikan dalam bentuk tabel secara rapi dan terstruktur dengan menggunakan check sheet.

2. Membuat Peta Kendali $p$ ( $p$ chart)

Peta kendali $p$ (peta kendali proporsi kerusakan) sebagai alat untuk pengendalian proses secara statistik. Penggunaan peta kendali $p$ ini dikarenakan pengendalian kualitas yang dilakukan bersifat atribut.

Adapun langkah-langkah dalam membuat peta kendali $p$ menurut Jay Haizer \& Barry Render (2006) sebagai berikut:

a. Menghitung Presentase Kerusakan

$$
\mathrm{P}=\frac{n}{p}
$$

b. Menghitung garis pusat/Central Line (CL)

$$
\mathrm{CL}=\bar{p}=\frac{\sum n p}{\sum n}
$$


c. Menghitung simpangan baku (Sp)

$$
\mathrm{S} p=\sqrt{\frac{\bar{p}(1-\bar{p})}{\overline{\mathrm{n}}}}
$$

d. Menghitung batas kendali atas atau Upper Control Limit (UCL)

$$
\mathrm{UCL}=\bar{p}+3 S p
$$

e. Menghitung batas kendali bawah atau Lower Control Limit (LCL)

LCL $: \bar{p}-3 S p$

\section{HASIL DAN PEMBAHASAN}

Untuk mempertahankan kualitas produk yang dihasilkan, PT. Radar Sulteng Membangun melaksanakan aktivitas pengendalian kualitas melalui tiga tahapan, antara lain:

1. Pengendalian terhadap bahan baku

2. Pengendalian terhadap proses produksi

3. Pengendalian terhadap produk jadi

Penyelesaikan permasalahan pengendalian kualitas statistik secara atribut akan dilakukan langkahlangkah sebagai berikut:

1. Mengumpulkan data menggunakan lembar periksa (Check sheet)

2. Membuat peta kendali $p$ ( $p$ Chart)

Mengumpulkan data menggunakan lembar periksa (Check sheet)

\begin{tabular}{|c|c|c|c|c|c|c|c|c|c|c|}
\hline \multirow[b]{2}{*}{ No } & \multirow[b]{2}{*}{$\begin{array}{l}\text { Tanggal } \\
\text { Produksi }\end{array}$} & \multirow[b]{2}{*}{$\begin{array}{c}\text { Jumlah } \\
\text { Produksi } \\
\text { (Eksemplar) }\end{array}$} & \multicolumn{5}{|c|}{ Jenis Produk Cacat (Halaman) } & \multirow{2}{*}{$\begin{array}{c}\text { Jumlah } \\
\text { Produk } \\
\text { Cacat } \\
\text { (Hal) }\end{array}$} & \multirow[b]{2}{*}{$\begin{array}{l}\text { Persentase } \\
\text { Cacat }(\%)\end{array}$} & \multirow[b]{2}{*}{$\begin{array}{c}\text { Proporsi } \\
\text { Cacat }\end{array}$} \\
\hline & & & $\begin{array}{l}\text { Koran } \\
\text { Kotor }\end{array}$ & $\begin{array}{l}\text { Warna } \\
\text { Kabur }\end{array}$ & Terpotong & $\begin{array}{l}\text { Tidak } \\
\text { Register }\end{array}$ & $\begin{array}{l}\text { Tidak } \\
\text { Simetris }\end{array}$ & & & \\
\hline 1 & $1 / 3 / 2018$ & 2680 & 0 & 4 & 0 & 1 & 2 & 7 & $0.3 \%$ & 0.031 \\
\hline 2 & $2 / 3 / 2018$ & 2489 & 1 & 5 & 0 & 1 & 2 & 9 & $0.4 \%$ & 0.040 \\
\hline 3 & $3 / 3 / 2018$ & 2640 & 0 & 10 & 0 & 1 & 2 & 13 & $0.5 \%$ & 0.057 \\
\hline 4 & $4 / 3 / 2018$ & 2238 & 1 & 12 & 0 & 1 & 3 & 17 & $0.8 \%$ & 0.075 \\
\hline 5 & $5 / 3 / 2018$ & 2595 & 1 & 3 & 0 & 0 & 3 & 7 & $0.3 \%$ & 0.031 \\
\hline 6 & $6 / 3 / 2018$ & 2539 & 0 & 4 & 1 & 0 & 3 & 8 & $0.3 \%$ & 0.035 \\
\hline 7 & $7 / 3 / 2018$ & 2591 & 1 & 14 & 0 & 1 & 1 & 17 & $0.7 \%$ & 0.075 \\
\hline 8 & $8 / 3 / 2018$ & 2490 & 0 & 5 & 1 & 1 & 3 & 10 & $0.4 \%$ & 0.044 \\
\hline 9 & $9 / 3 / 2018$ & 2572 & 2 & 6 & 0 & 0 & 4 & 12 & $0.5 \%$ & 0.053 \\
\hline 10 & $11 / 3 / 2018$ & 2628 & 2 & 8 & 0 & 1 & 2 & 13 & $0.5 \%$ & 0.057 \\
\hline 11 & $12 / 3 / 2018$ & 2255 & 1 & 11 & 0 & 0 & 3 & 15 & $0.7 \%$ & 0.066 \\
\hline 12 & $13 / 3 / 2018$ & 2560 & 1 & 3 & 0 & 2 & 2 & 8 & $0.3 \%$ & 0.035 \\
\hline 13 & $14 / 3 / 2018$ & 2429 & 6 & 4 & 2 & 4 & 1 & 17 & $0.7 \%$ & 0.075 \\
\hline 14 & $16 / 3 / 2018$ & 2559 & 1 & 5 & 0 & 0 & 3 & 9 & $0.4 \%$ & 0.040 \\
\hline 15 & $17 / 3 / 2018$ & 2480 & 1 & 7 & 0 & 0 & 3 & 11 & $0.4 \%$ & 0.048 \\
\hline 16 & $18 / 3 / 2018$ & 2430 & 1 & 2 & 0 & 0 & 5 & 8 & $0.3 \%$ & 0.035 \\
\hline 17 & $19 / 3 / 2018$ & 2310 & 0 & 5 & 0 & 3 & 4 & 12 & $0.5 \%$ & 0.053 \\
\hline 18 & $20 / 3 / 2018$ & 2351 & 1 & 6 & 3 & 1 & 4 & 15 & $0.6 \%$ & 0.066 \\
\hline 19 & $21 / 3 / 2018$ & 2468 & 1 & 6 & 0 & 1 & 4 & 12 & $0.5 \%$ & 0.053 \\
\hline \multirow[t]{2}{*}{20} & $24 / 3 / 2018$ & 2423 & 0 & 3 & 1 & 1 & 2 & 7 & $0.3 \%$ & 0.031 \\
\hline & Total & 49727 & 21 & 123 & 8 & 19 & 56 & 227 & & \\
\hline
\end{tabular}

Tabel 1. Lembar Periksa (Check Sheet)

Sumber: Data primer yang diolah,2018 
Hasil perhitungan tabel 1 di atas menunjukkan bahwa jumlah produksi koran sebanyak 49,727 eksemplar dengan total kerusakan 21 halaman dari 20 eksemplar selama 20 hari kerja, selanjutnya dapat dihitung pengendalian kualitas produk dengan menggunakan Stastistic Quality Control (SQC) dengan pendekatan peta kendali $p$ yang menggunakan standar deviasi 3, maka selanjutnya dapat dibuat peta kendali $p$ yang dapat dilihat pada gambar berikut ini:

\section{Gambar 1. Peta Kendali $p$ (p chart) Koran Kotor}

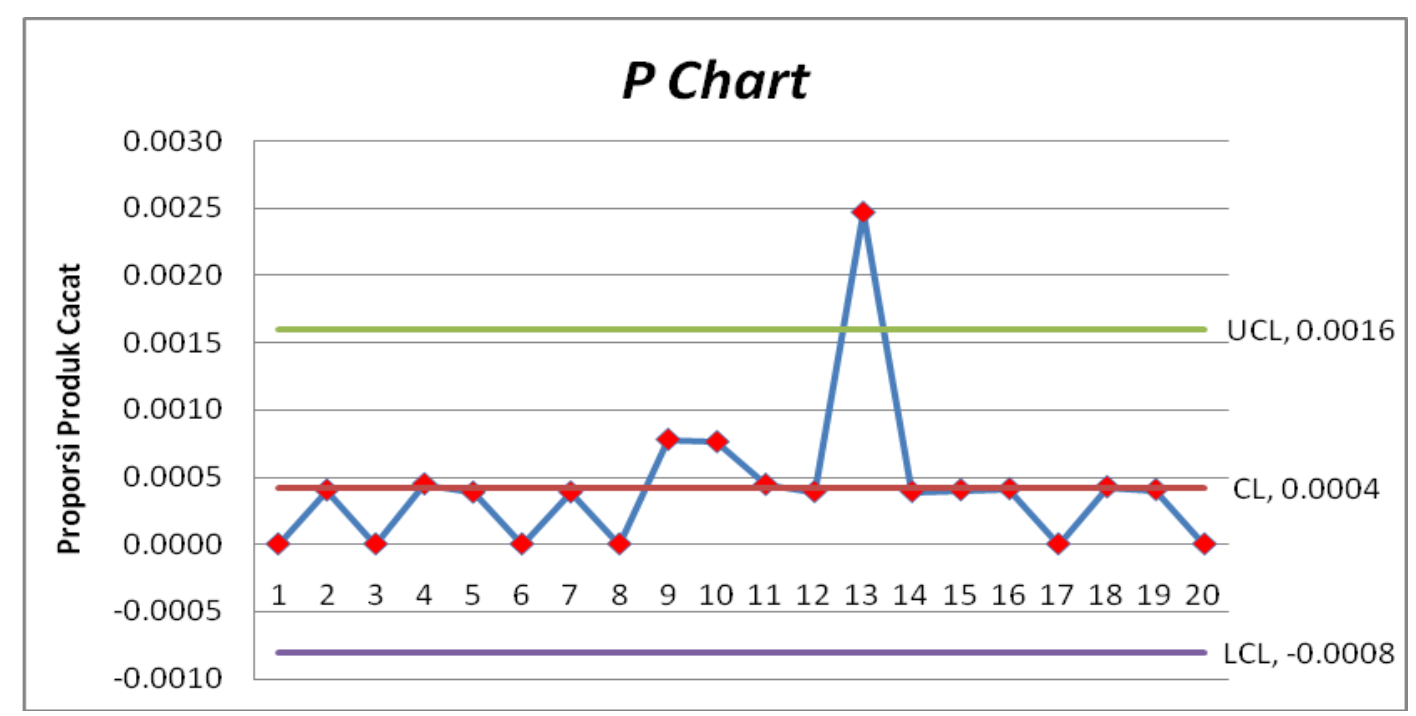

Sumber: Data primer yang diolah,2018

Berdasarkan gambar 1 hasil pengolahan data yang digunakan menggunakan standar deviasi 3 menunjukkan ada 1 titik sampel yang berada diluar batas kendali atas (UCL). Untuk mengetahui jika proses control masih dalam batas kendali atau diluar batas kendali yaitu jika produk cacat/ rusak mencapai atau berada diatas batas kendali atas (UCL) maka proses produksi yang dilakukan dianggap tidak efektif. Sebaliknya produk cacat/ rusak berada pada batas kendali bawah (LCL) berarti proses produksi menunjukkan cukup efektif.

Selanjutnya produk koran yang mempunyai cacat/ kerusakan yang berada diluar batas kendali atas (UCL) yaitu terjadi pada hari ke 13 sedangkan yang berada diluar batas kendali bawah (LCL) tidak ada. Adapun besarnya nilai garis sentral (CL) yaitu 0.0004, nilai batas kendali atas (UCL) yaitu 0.0016, nilai batas kendali bawah (LCL) -0.0008 dengan nilai proporsi cacat 0.0085 yang berarti proses pengendalian kualitas masih dalam keadaan terkendali karena nilai proporsi cacat lebih besar dari LCL. Penyebab dari 1 titik sampel yang berada diluar batas kendali pada hari ke 13 dikarenakan kepekatan tinta tidak pas sesuai takaran sehingga penyerapan tinta tidak merata dan terjadi bercak-bercak tinta pada lembaran koran.

\section{Gambar 2. Peta Kendali $p$ (p chart) Warna Kabur}




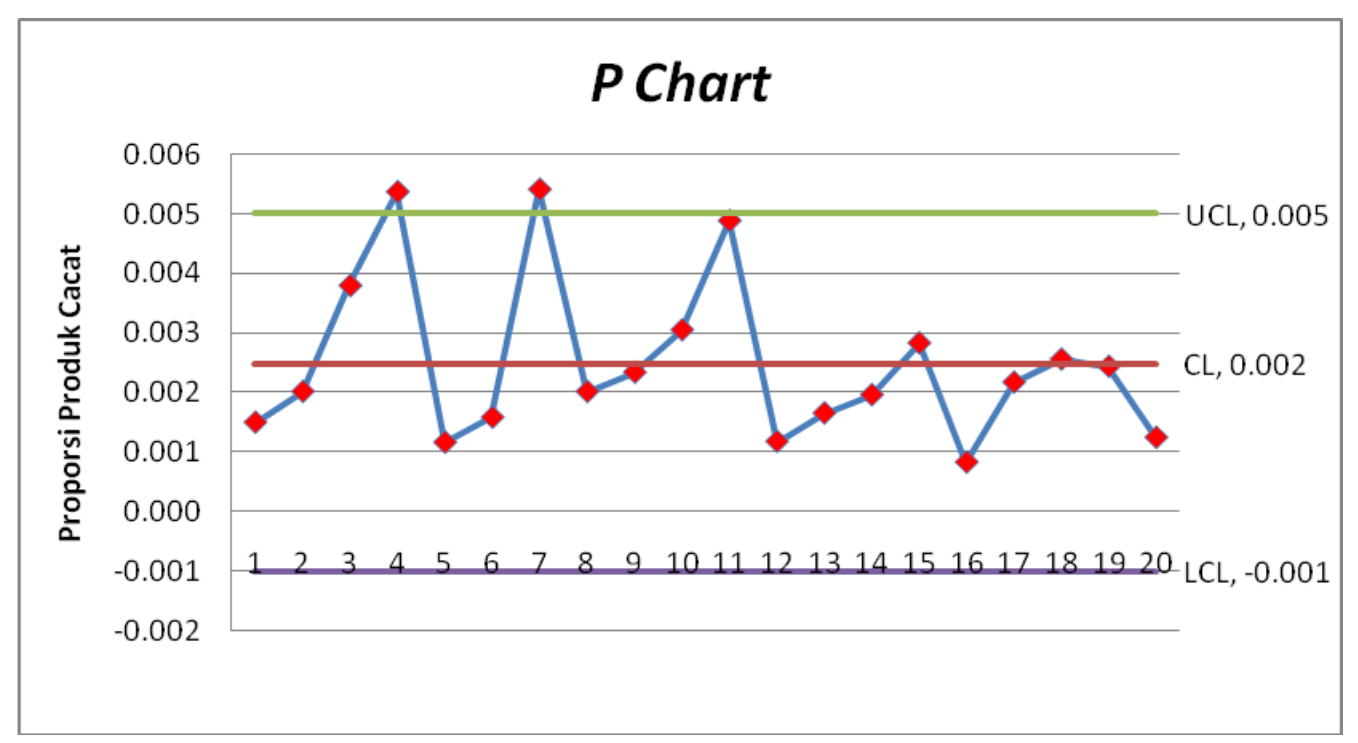

Sumber: Data primer yang diolah,2018

Berdasarkan gambar 2 di atas hasil pengolahan data yang menggunakan standar deviasi 3 menunjukan besarnya nilai garis sentral (CL) yaitu 0.002, nilai batas kendali atas (UCL) 0,005 dan nilai batas kendali bawah (LCL) -0.001. Untuk mengetahui jika proses kontrol masih dalam batas kendali atau diluar batas kendali yaitu jika produk yang cacat/rusak mencapai atau berada di atas batas kendali atas (UCL) maka proses produksi yang dilakukan dianggap tidak efektif. Sebaliknya produk cacat/rusak berada pada batas kendali bawah (LCL) berarti proses produksi menunjukan cukup efektif. Selanjutnya produk koran yang mempunyai cacat/kerusakan yang berada diluar batas kendali atas (UCL) yaitu terjadi pada hari ke 4 dan 7 sedangkan yang berada di luar batas kendali bawah (LCL) tidak ada. Terdapat dua titik yang berada diluar batas kendali atas (UCL) yang menunjukkan terjadi kekeliruan dalam proses produksi koran pada PT. Radar Sulteng Membangun. Penyebab dari dua titik yang berada diluar batas kendali pada hari ke 4 dan 7 dikarenakan pemasangan plate tidak sejajar sehingga menimbulkan salah cetak seperti tidak register atau menjadikan warna kabur.

\section{Gambar 3. Peta Kendali $p$ ( $p$ chart) Koran Terpotong}


JURNAL ILMU MANAJEMEN UNIVERSITAS TADULAKO

Vol. 5, No. 3, September 2019, p. $287-297$

ISSN : 2443-3578 (On Line) / ISSN : 2443-1850 (Print)

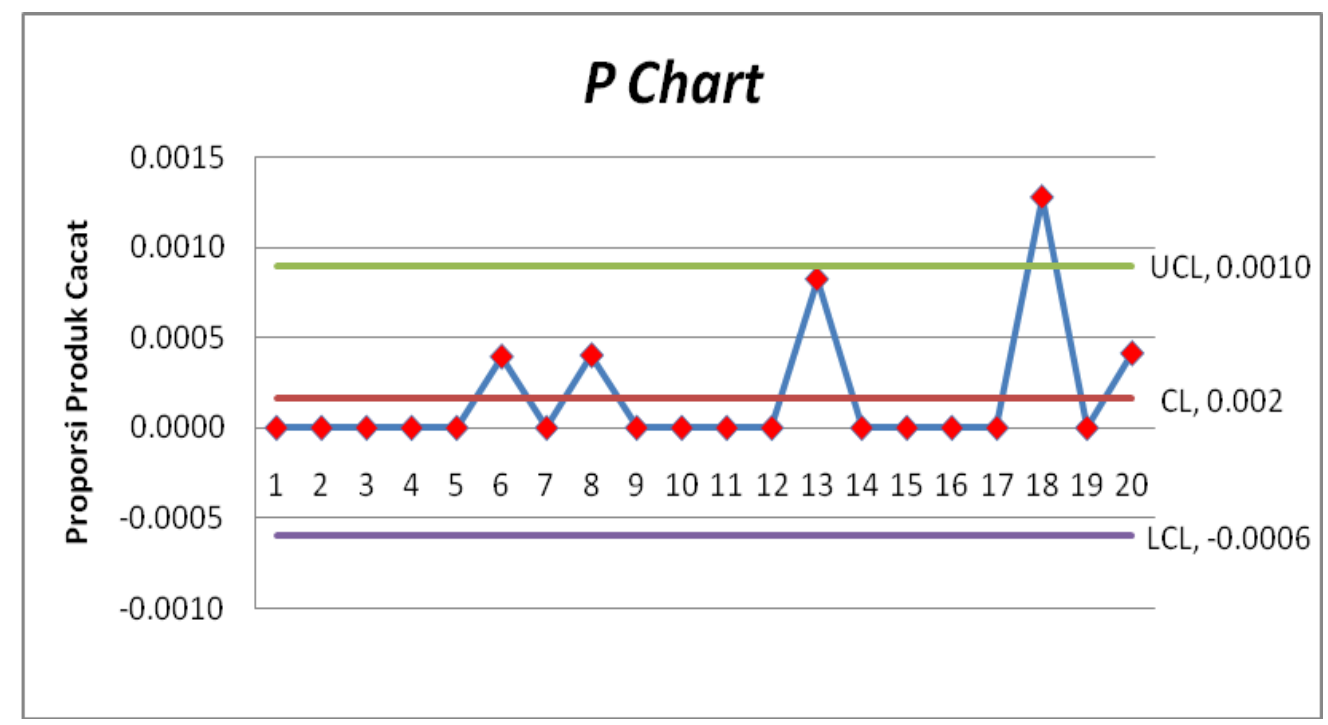

Sumber: Data primer yang diolah,2018

Berdasarkan Gambar 3 hasil pengolahan data yang menggunakan standar deviasi 3 besarnya nilai garis sentral (CL) yaitu 0.002, nilai batas kendali atas (UCL) 0.0010 dan nilai batas kendali bawah (LCL)

-0.0006. Untuk mengetahui jika proses kontrol masih dalam batas kendali atau diluar batas kendali yaitu jika produk yang cacat/rusak mencapai atau berada di atas batas kendali atas (UCL) maka proses produksi yang dilakukan dianggap tidak efektif. Sebaliknya produk cacat/rusak berada pada batas kendali bawah (LCL) berarti proses produksi menunjukan cukup efektif.

Selanjutnya produk koran yang mempunyai cacat/kerusakan yang berada diluar batas kendali atas (UCL) yaitu terjadi pada hari ke 18 sedangkan yang berada di luar batas kendali bawah (LCL) tidak ada. Terdapat 1 titik yang berada diluar batas kendali atas (UCL) yang menunjukkan terjadi kekeliruan dalam proses produksi koran pada PT. Radar Sulteng Membangun. Penyebab dari 1 titik yang berada diluar batas kendali pada hari ke 18 dikarenakan pemasangan kertas tidak persisi sehingga terjadi unregister dan terpotong.

Gambar 4. Peta Kendali $p$ (p chart) Koran Tidak Register 
JURNAL ILMU MANAJEMEN UNIVERSITAS TADULAKO

Vol. 5, No. 3, September 2019, p. $287-297$

ISSN : 2443-3578 (On Line) / ISSN : 2443-1850 (Print)

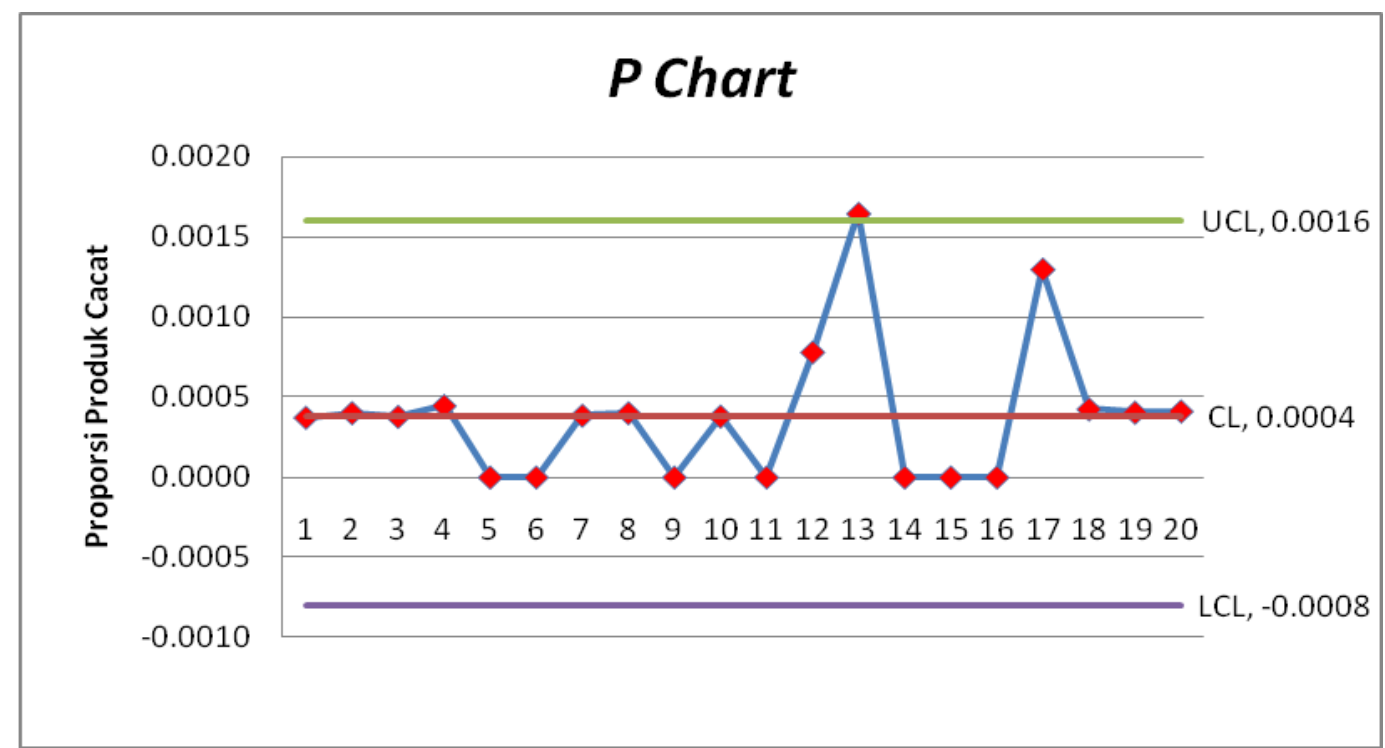

Sumber: Data primer yang diolah,2018

Berdasarkan Gambar 4 hasil pengolahan data yang menggunakan standar deviasi 3 menunjukkan tidak ada titik sampel yang berada diluar batas kendali, hal ini menunjukkan bahwa peta kendali $p$ untuk produk koran tidak register masih dalam batas pengendalian karena titik-titik observasi tidak ada yang melewati batas nilai UCL dan batas nilai LCL.

Gambar 5. Peta Kendali $p$ (p chart) Koran Tidak Simetris

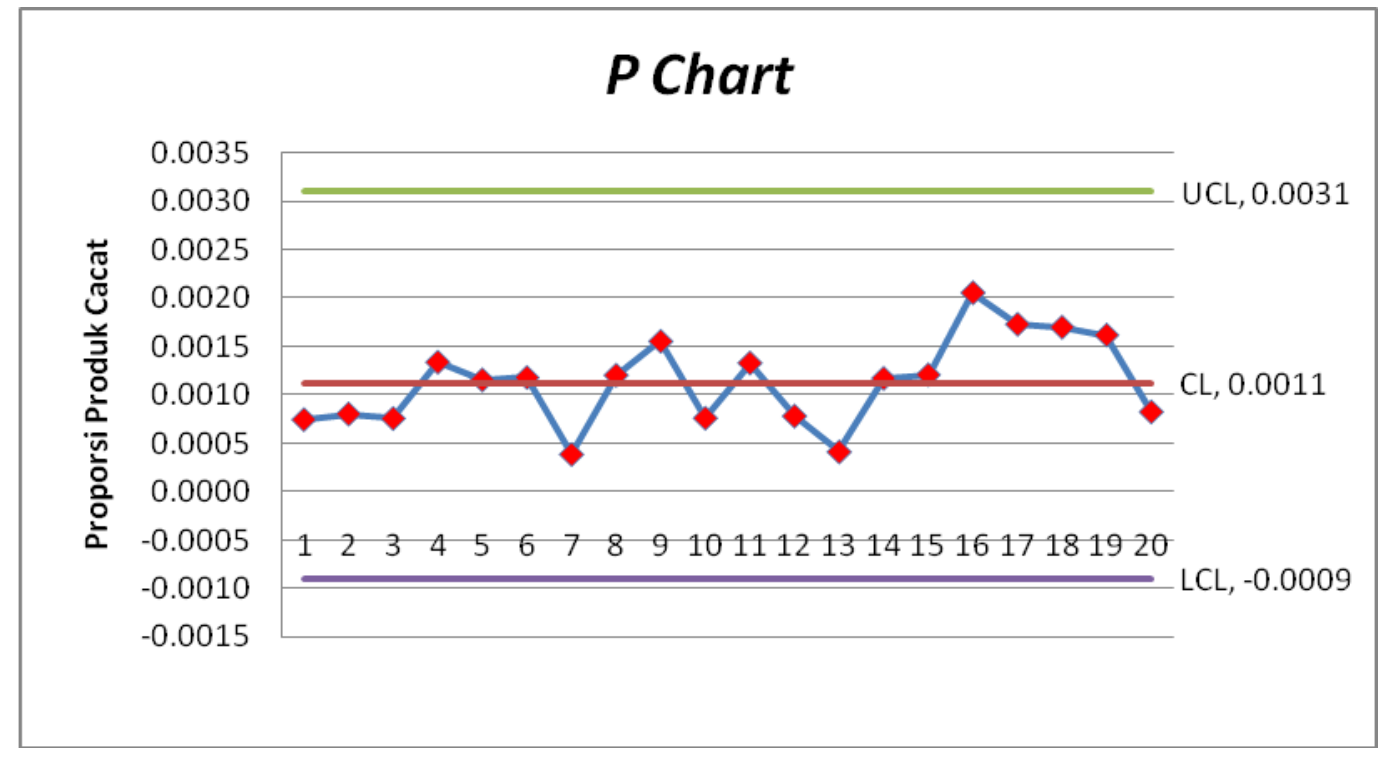

Sumber: Data primer yang diolah,2018

Berdasarkan Gambar 5 hasil pengolahan data yang menggunakan standar deviasi 3 menunjukkan tidak ada titik sampel yang berada diluar batas kendali, hal ini menunjukkan bahwa peta kendali $p$ untuk produk koran tidak register masih dalam batas pengendalian karena titik-titik observasi tidak ada yang melewati batas nilai UCL dan batas nilai LCL. 


\section{Gambar 6. Peta Kendali $p$ (p chart) Koran Batas Kendali Bulan Maret 2018}

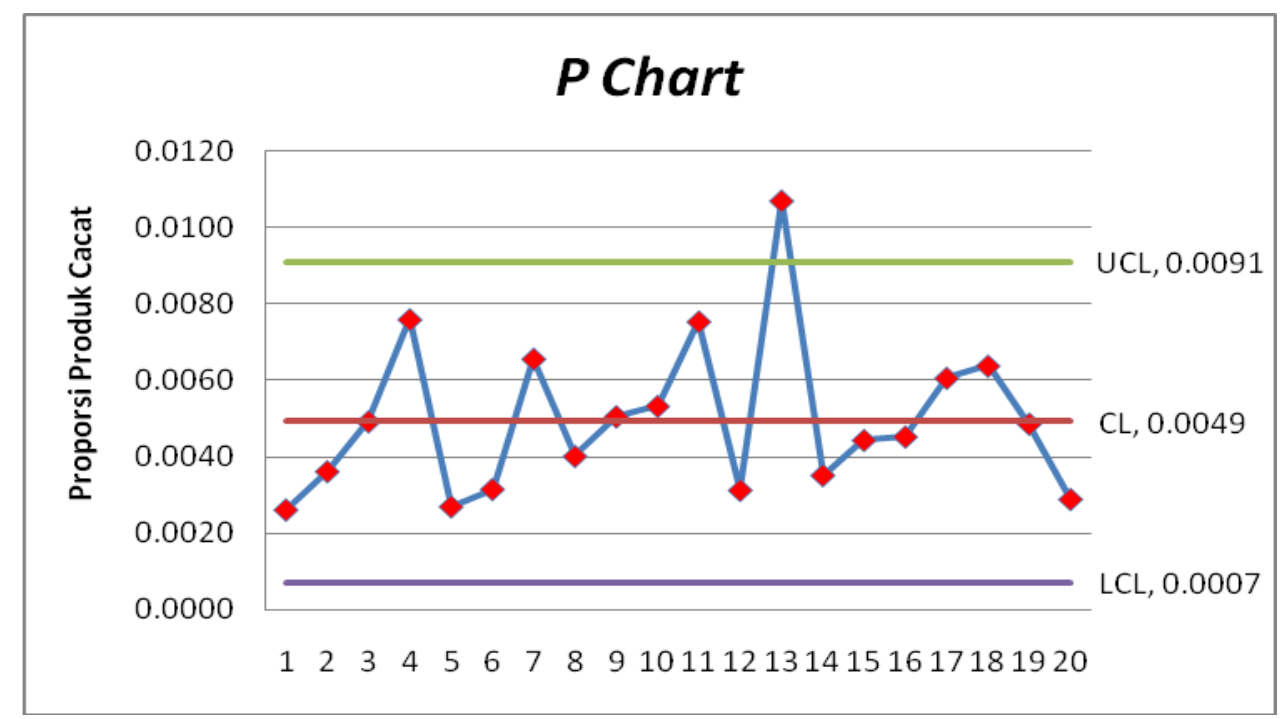

Sumber: Data primer yang diolah,2018

Berdasarkan Gambar 6 hasil pengolahan data yang menggunakan standar deviasi 3 ada 1 titik sampel yang berada diluar batas kendali atas (UCL). Besarnya nilai garis sentral (CL) yaitu 0.0049, nilai batas kendali atas (UCL) 0.0091 dan nilai batas kendali bawah (LCL) 0.007 dengan proporsi cacat sebanyak 0.0050 yang berarti proses pengendalian kualitas berada dalam keadaan terkendali karena nilai proporsi cacat lebih kecil dari UCL.

\section{PENUTUP}

Pengendalian kualitas produk akhir pada PT. Radar Sulteng Membangun dengan jumlah sampel 49.727 eksemplar dalam 20 hari kerja menunjukkan:

1. Jenis koran kotor masih belum terkendali.

2. Jenis warna kabur masih belum terkendali.

3. Jenis koran terpotong masih belum terkendali.

4. Jenis koran tidak register sudah terkendali.

5. Jenis koran tidak simetris sudah terkendali.

Berdasarkan analisis menggunakan alat bantu statistik yang telah dilakukan, maka penulis mengajukan saran-saran kepada pihak PT. Radar Sulteng Membangun yang dapat dijadikan bahan pertimbangan untuk pengendalian kualitas adalah sebagai berikut:

1. Membuat suatu tim pengawas yang bertugas mengawasi dan mengecek ulang kinerja operator sehingga dapat mengurangi kesalahan yang disebabkan oleh human error.

2. Membuat suatu tim pengawas yang bertugas mengawasi dan mengecek ulang kinerja operator sehingga dapat mengurangi kesalahan yang disebabkan oleh human error. Selain itu, sebaiknya tinta yang digunakan diperiksa kembali apakah tinta itu masih sesuai spesifikasi atau tidak (misalnya tinta tidak terlalu kental). Perawatan mesin juga sangat penting, melakukan perawatan mesin secara rutin tidak hanya dilakukan ketika mesin mengalami kerusakan. 
3. Perlu ditambahkan fasilitas yang berfungsi untuk mengurangi suhu udara yang disebabkan oleh mesin dan cuaca, seperti penambahan kipas angin pada setiap sudut, atau kipas angin mini untuk setiap tempat operator. Selain itu, melakukan pengecekan mesin yang rutin juga dapat meminimalkan tingkat kesalahan yang disebabkan oleh mesin. Oleh karena itu perawatan mesin yang rutin dapat menjaga kestabilan mesin saat berproduksi.

\section{REFERENSI}

Assauri, Sofjan, 2008. Manajemen Operasi, LP FE UI: Jakarta.

Ariani, Dorothea Wahyu, 2003. Pengendalian Kualitas Statistik (Pendekatan Kuantitatif dalam Manajemen Kualitas), ANDI Yogyakarta: Yogyakarta.

Cawley, J dan Harrold, D. 1999. SPC and SQC Provide The Big Processing Performance Control Engineering.

Heizer, J dan Render, B. 2006. Operation Management edisi ketujuh. Salemba Empat: Jakarta.

Montgomery, Doughlas C, 2001. Introduction to Statistical Quality. ${ }^{\text {th }}$ Edition. New York: John wiley \& Sons, Inc.

Nasution, Arman Hakim, 2005. Manajemen Industri. Andi Yogyakarta: Yogyakarta.

Prawirosentono, Suyadi, 2007. Filosofi baru tentang Manajemen Mutu Terpadu Abad 21. Bumi Aksara: Jakarta.

Sugiyono, 2014. Metode Penelitian Bisnis (Pendekatan Kuantitatif, Kualitatif, R\&D), Alfabeta: Bandung 